Rostyslav Romanyuk, Nataliya Romanyuk Ivan Franko National University of Lviv, Ukraine

\title{
THE CRIMEA PROBLEM (2014): A THEORETICAL RECONSTRUCTION FROM THE PERSPECTIVE OF THE INTERNATIONAL RELATIONS THEORY
}

\begin{abstract}
The article aims to present the current situation in Ukraine through international relations theory that is able to provide the necessary theoretical background to analyse the complex problems that unfold in the contemporary international environment. These problems are analysed through several perspectives including realist, postmodern and socialconstructivist dimensions, as well as from the point of view of classical institutionalism. What is more, on the basis of their deliberations, the authors describe several possible scenarios of the future events, including the strategy of Russia to continue destabilization in Ukraine in order to seize control over its entire territory and the long-term effects of international sanctions on the Russian economy with the possibility of the collapse of the aggressor state. Nonetheless, the Crimean crisis reveals an important fact that, according to the authors, has deep ramifications for the entire international security system - at present, the international community is not able to exert influence on any of the nuclear powers through military means. While other, non-military means of influence can be used, such as broad economic sanctions or political isolation of an aggressor-state, they are not effective immediately thus allowing the aggressor states to violate international law with a feeling of impunity and invincibility.
\end{abstract}

\section{Key words}

the Crimean crisis, Ukraine, international relations theory, international security system, military aggression 